PROFESI (Profesional Islam)

Media Publikasi Penelitian; 2017; Volume 15; No 1.

Website: ejournal.stikespku.ac.id

\title{
Perbedaan Perubahan Status Gizi Berdasarkan BB/TB dan IMT/U pada Balita yang Mengikuti Dengan yang Tidak Mengikuti TFC di Kabupaten Sukoharjo
}

\author{
Mia Sufia Adnin ${ }^{1 *}$, Luluk Ria Rakhma ${ }^{2}$ \\ ${ }^{1}$ Prodi Ilmu Gizi/Fakultas Ilmu Kesehatan, Universtas Muhammadiyah Surakarta \\ ${ }^{2}$ Prodi Ilmu Gizi/Fakultas Ilmu Kesehatan, Universitas Muhammadiyah Surakarta \\ *Email: mia.sofia76@gmail.com
}

Kata Kunci
Balita,
Antropometri,
Status gizi,
TFC,
Z-score

Kata Kunci

Balita, Antropometri, Status gizi,

Z-score 


\section{PENDAHULUAN}

Penyebabkan banyaknya balita yang meninggal salah satunya gizi kurang. Gizi kurang adalah suatu kondisi dimana seseorang dinyatakan kekurangan nutrisi, atau dengan ungkapan lain status gizinya berada di bawah standar ratarata (Depkes RI, 2003). Gizi kurang berpotensi terhadap angka kematian pada balita. Setiap tahun terdapat 12 juta anak meninggal sebelum usia 5 tahun dan $70 \%$ meninggal karena pneumonia, diare, malaria, campak, malnutrisi dan tidak sedikit dari kematian itu merupakan kombinasi dari penyakit tersebut (Depkes RI, 2011). Survei demografi dan kesehatan Indonesia (SDKI) tahun 2012 menunjukkan bahwa angka kematian bayi (AKB) di Indonesia sebesar 32 per 1000 kelahiran hidup dan angka kematian Balita (AKABA) sebesar 40 per 1000 kelahiran hidup, itu berarti kematian balita (0-59 bulan) masih sedang (SDKI, 2012).

Status gizi itu sendiri merupakan keadaan tubuh yang diakibatkan oleh konsumsi makanan dan asupan zat-zat gizi (Almatsier, 2009). Zat gizi sangat penting untuk memenuhi gizi seimbang bagi balita agar status gizi balita menjadi baik. Seperti pendapat dari Puspitawati dan Sulistyarini (2013), dengan terpenuhinya gizi yang baik, tubuh dapat mempertahankan diri terhadap penyakit infeksi dan sebaliknya gangguan gizi dapat memperburuk kemampuan anak untuk mengatasi penyakit infeksi. Disamping itu, apabila anak mengalami status gizi kurang maka dapat menyebabkan kekurangan gizi seperti energi, protein, zat besi yang menyebabkan berbagai keterbatasan antara lain pertumbuhan mendatar, berat badan dan tinggi badan menyimpang dari pertumbuhan normal dan lain-lain dan pada akhirnya menye-babkan keterlambatan pertumbuhan. Dampak yang lebih serius lagi adalah timbulnya ke-cacatan, tingginya angka kesakitan dan per-cepatan kematian (Rahim, 2014).

Penyebab masalah gizi dipengaruhi oleh dua faktor yaitu faktor langsung dan faktor tidak lagsung. Penyebab langsung yaitu faktor asupan makanan dan penyakit infeksi (Adisasmito, 2007). Makanan yang dikonsumsi sehari-hari mengandung zat-zat yang diperlukan oleh tubuh. Semakin banyak zat-zat gizi yang terkandung dalam makanan yang dimakan maka semakin baik status gizi yang dimiliki-nya. Faktor penyakit infeksi, dalam keadaan gizi yang baik, tubuh mempunyai cukup kemam-puan untuk mempertahankan diri terhadap penyakit infeksi. Jika keadaan gizi semakin buruk maka reaksi kekebalan tubuh akan menurun yang berarti kemampuan tubuh untuk mempertahankan diri terhadap serangan infeksi menjadi turun. Infeksi memperburuk status gizi dan sebaliknya gangguan gizi memperburuk kemampuan anak untuk mengatasi penyakit infeksi (Aritonang, 2003). Faktor penyebab tidak langsung yaitu ketahanan pangan dalam keluarga, pola asuh, pelayanan kesehatan dan sanitasi lingkungan yang kurang memadai. Keempat faktor tidak langsung tersebut saling berkaitan dengan pendidikan, pengetahuan, penghasilan dan keterampilan ibu (Adisasmito, 2007).

Gizi kurang tidak hanya terjadi di Indonesia saja melainkan juga terjadi di negara berkembang lainnya. Menurut data Riskesdas pada tahun 2013 yang menggunakan indeks $\mathrm{BB} / \mathrm{TB}$ terdapat $12,1 \%$ balita wasting (kurus) yang terdiri dari 6,8\% balita kurus dan 5,3\% sangat kurus. Data Riskesdas (2010), terdapat 6,0\% balita sangat kurus dan $7,3 \%$ balita kurus. Data Riskesdas (2007), terdapat $6,2 \%$ balita sangat kurus dan $7,4 \%$ balita kurus. Akan tetapi hal tersebut akan mengalami kenaikan prevalensi anak balita apabila tidak diperhatikan terhadap penyebab masalah gizi pada balita untuk waktu yang akan datang. Indikator $\mathrm{BB} / \mathrm{TB}$ dapat menggambarkan keadaan status gizi akut dan dapat menggambarkan keadaan status gizi saat ini dan IMT/U dapat menggambarkan keadaan status gizi masa lalu dan masa kini.

Sasaran program perbaikan gizi pada kalangan anak balita dianggap strategis dalam upaya menanggulangi masalah gizi. Perlu mengembangkan pengetahuan gizi pada ibu balita yang dilaksanakan dengan cara berkoordinasi tokoh masyarakat dengan petugas kesehatan atau puskesmas dan posyandu agar selalu meningkatkan dalam menanggulangi 
masalah gizi kurang pada anak balita. Pemerintahan melakukan program untuk mengurangi gizi kurang pada balita seperti posyandu, membentuk Tim Asuhan Gizi yang terdiri dari dokter, perawat, bidan, ahli gizi, serta di bantu oleh tenaga kesehatan yang lain (Depkes RI, 2010), dan pemberian PMT yaitu salah satunya dengan menyediakan program Therapeutic Feeding Center (TFC) di puskesmas. Therapeutic Feeding Center (TFC) merupakan tempat perawatan bagi balita yang mengalami kekurangan gizi. Perawatan dilakukan setiap minggu sekali dengan metode seperti rapat bersama atau musyawarah dan dalam kegiatan tersebut ibu balita dan balita diberikan edukasi gizi, PMT maupun kegiatan yang lain untuk menangani kasus permasalahan gizi (Kemenkes RI, 2011). Penelitian Tumiar (2008), mengatakan PMT yang diberikan pada balita gizi kurang bertujuan memberikan asupan yang tinggi, tinggi protein, dan cukup vitamin dan mineral secara bertahap, guna mencapai status gizi yang optimal dengan komposisi zat gizi mencukupi. Begitu juga dengan penelitian Maria, dkk. (2012), mengatakan ada perbedaan berat badan sebelum dan sesudah pemberian makanan tambahan $(\mathrm{p}<0,05)$. Perubahan terlihat selama 1 bulan masa perawatan yaitu berat badan sesudah perawatan dikurangi berat badan sebelum perawatan yakni berat badan rata-rata sebelum perawatan yaitu $7,34 \mathrm{~kg}$ dan sesudah atau akhir perawatan ratarata berat badan yaitu 8,08 dan mengalami perubahan yakni sebesar rata-rata $0,74 \mathrm{~kg}$.

Hasil dari Dinkes Sukoharjo tahun 2015, menunjukkan bahwa balita yang menderita gizi kurang berdasarkan $\mathrm{BB} / \mathrm{U}$ di Kabupaten Sukoharjo berjumlah 2209 balita atau $4,67 \%$ sedangkan hasil Dinkes tahun 2016 pada bulan Oktober, balita yang menderita gizi kurang berdasarkan BB/U naik menjadi 2476 balita atau $4,98 \%$.

Kenyataannya setiap tahun semakin bertambah penderita gizi kurang pada balita walaupun perkembangan jaman semakin maju. Maka perlu adanya solusi untuk mengatasi masalah tersebut antara lain dengan memberikan penyuluhan tentang program TFC di Puskesmas kepada para ibu yang memiliki anak balita. Berdasarkan data yang telah diuraikan diatas maka penulis tertarik untuk melakukan penelitian dengan mengangkat judul "Perbedaan Perubahan Status Gizi Berdasarkan BB/TB dan IMT/U pada Balita yang Mengikuti dengan yang Tidak Mengikuti Program TFC".

\section{METODE PENELITIAN}

Jenis penelitian yang digunakan bersifat Quasi Eksperimental dengan pendekatan cross sectional, yaitu variabel terikat pre dan post kontrol diukur dan diamati pada waktu yang bersamaan. Penelitian akan mengambil data variabel bebas yaitu partisipasi program TFC dan data variabel terikat yaitu status gizi (BB/TB dan IMT/U). Lokasi penelitian untuk yang mengikuti progam TFC di Kecamatan Weru, Kecamatan Gatak dan Kecamatan Sukoharjo sedangkan yang tidak mengikuti progam TFC di Kecamatan Sukoharjo yaitu dikelurahan Bulakrejo dan kelurahan Sukoharjo. Populasi dalam penelitian ini adalah balita yang mengalami gizi kurang di Kecamatan Weru, Kecamatan Gatak dan Kecamatan Sukoharjo. Teknik pengambilan sampel penelitian ini menggunakan teknik total sampling yaitu yaitu teknik pengambilan sampel dimana jumlah sampel sama dengan jumlah populasi (Sugiyono, 2007) dan simple random sampling yaitu pengambilan sampel secara acak sederhana, teknik ini dibedakan menjadi dua cara yaitu dengan mengundi atau dengan menggunakan tabel bilangan atau angka acak (Notoatmodjo, 2010).

Alat yang digunakan dalam penelitian ini adalah microtoice, baby board, timbangan injak atau dacin, dan alat tulis. Instrumen yang digunakan dalam penelitian ini adalah formulir identitas responden, digunakan untuk mengetahui data tentang karakteristik responden (nama, jenis kelamin, umur, tanggal lahir), program komputer SPSS 16.0. Pada analisis univariat, hasil yang dianalisis antara lain data usia, jenis kelamin dan status gizi (BB/TB dan IMT/U) responden, sedangkan analisis bivariat untuk mengetahui kenormalan data menggunakan uji statistik Kolmogorov Smirnov. Hasil uji kenormalan data 
PROFESI (Profesional Islam) Media Publikasi Penelitian; 2017; Volume 15; No 1.

Website: ejournal.stikespku.ac.id

bersifat normal, sehingga menguji perbedaan menggunakan Uji T-test Independent. Interpretasi hasil dari uji T-test Independent dinyatakan terdapat perbedaan jika nilai $\mathrm{p}<0,05$ dan dinyatakan tidak ada perbedaan jika nilai $\mathrm{p} \geq$ 0,05 .

\section{HASIL DAN PEMBAHASAN}

\subsection{Analisi Univariat}

Tabel 1. Distribusi Frekuensi Karakteristik Responden

\begin{tabular}{|c|c|c|}
\hline Karakteristik Responden & $\begin{array}{c}\text { Jumlah } \\
\text { (n) }\end{array}$ & $\begin{array}{c}\text { Presentase } \\
(\%)\end{array}$ \\
\hline \multicolumn{3}{|l|}{ TFC } \\
\hline \multicolumn{3}{|l|}{ Umur Balita } \\
\hline 7-36 bulan & 25 & $83,3 \%$ \\
\hline $37-60$ bulan & 5 & $16,7 \%$ \\
\hline \multicolumn{3}{|l|}{ Jenis Kelamin } \\
\hline Laki-Laki & 11 & $36,7 \%$ \\
\hline Perempuan & 19 & $63,3 \%$ \\
\hline \multicolumn{3}{|l|}{ Status Gizi Awal BB/TB } \\
\hline Normal & 13 & $43,3 \%$ \\
\hline Gizi Kurus & 10 & $33,3 \%$ \\
\hline Gizi Sangat Kurus & 7 & $23,3 \%$ \\
\hline \multicolumn{3}{|l|}{ Status Gizi Awal IMT/U } \\
\hline Normal & 16 & $53,3 \%$ \\
\hline Gizi Kurang & 9 & $30 \%$ \\
\hline Gizi Sangat Kurang & 5 & $16,7 \%$ \\
\hline \multicolumn{3}{|l|}{ Status Gizi Akhir BB/TB } \\
\hline Normal & 22 & $62,8 \%$ \\
\hline Gizi Kurus & 12 & $34,3 \%$ \\
\hline Gizi Sangat Kurus & 1 & $2,9 \%$ \\
\hline \multicolumn{3}{|l|}{ Status Gizi Akhir IMT/U } \\
\hline Normal & 27 & $77,1 \%$ \\
\hline Gizi Kurang & 7 & $20 \%$ \\
\hline Gizi Sangat Kurang & 1 & $2,9 \%$ \\
\hline \multicolumn{3}{|l|}{ NON TFC } \\
\hline \multicolumn{3}{|l|}{ Umur Balita } \\
\hline 7-36 bulan & 21 & $70 \%$ \\
\hline $37-60$ bulan & 9 & $30 \%$ \\
\hline \multicolumn{3}{|l|}{ Jenis Kelamin } \\
\hline Laki-Laki & 19 & $63,3 \%$ \\
\hline Perempuan & 11 & $36,7 \%$ \\
\hline \multicolumn{3}{|l|}{ Status Gizi Awal BB/TB } \\
\hline Normal & 15 & $50 \%$ \\
\hline Gizi Kurus & 7 & $23,3 \%$ \\
\hline Gizi Sangat Kurus & 8 & $26,7 \%$ \\
\hline \multicolumn{3}{|l|}{ Status Gizi Awal IMT/U } \\
\hline Normal & 18 & $60 \%$ \\
\hline Gizi Kurang & 5 & $16,7 \%$ \\
\hline Gizi Sangat Kurang & 7 & $23,2 \%$ \\
\hline
\end{tabular}

\begin{tabular}{ccc}
\hline Status Gizi Akhir BB/TB & & \\
Normal & 19 & $63,3 \%$ \\
Gizi Kurus & 9 & $30 \%$ \\
Gizi Sangat Kurus & 2 & $6,7 \%$ \\
\hline Status Gizi Akhir IMT/U & & \\
Normal & 20 & $66,7 \%$ \\
Gizi Kurang & 7 & $23,3 \%$ \\
Gizi Sangat Kurang & 3 & $10 \%$ \\
\hline
\end{tabular}

Berdasarkan Tabel 1. Distribusi umur balita TFC tertinggi yaitu berusia 7-36 bulan sebanyak $85,7 \%$, distribusi jenis kelamin tertinggi yaitu perempuan sebanyak $57,1 \%$, distribusi status gizi awal $\mathrm{BB} / \mathrm{TB}$ tertinggi yaitu normal sebanyak 43,3\%, distribusi status gizi awal IMT/U tertinggi yaitu normal sebanyak $53,3 \%$, distribusi status gizi akhir BB/TB tertinggi yaitu normal sebanyak $62,8 \%$, dan distribusi status gizi akhir IMT/U tertinggi yaitu normal sebanyak $77,1 \%$.

Distribusi umur balita non TFC tertinggi yaitu berusia 7-36 bulan sebanyak 70\%, distribusi jenis kelamin tertinggi yaitu laki-laki sebanyak $63,3 \%$, distribusi status gizi awal BB/TB tertinggi yaitu normal sebanyak $50 \%$, distribusi status gizi awal IMT/U tertinggi yaitu normal sebanyak $60 \%$, distribusi status gizi akhir BB/TB yaitu normal sebanyak $63,3 \%$, dan distribusi status gizi akhir IMT/U yaitu normal sebanyak $66,7 \%$.

\subsection{Analisis Bivariat}

\subsubsection{Perbedaan Status Gizi Balita TFC dengan Non TFC Berdasarkan BB/TB}

Pengujian perbedaan perubahan status balita yang mengikuti program TFC dengan yang tidak mengikuti TFC berdasarkan BB/TB menggunakan uji T-Test Independent karena data penelitian berdistribusi normal. Hasil dapat dilihat pada Tabel 2.

Tabel 2. Perbedaan Status Gizi Balita TFC dengan non TFC Berdasarkan BB/TB

\begin{tabular}{ccrrrr}
\hline \multirow{2}{*}{ Program } & \multicolumn{4}{c}{ Zscore $\mathrm{BB} / \mathrm{TB}$} & $p$ - \\
\cline { 2 - 5 } & $\mathrm{n}$ & $\max$. & min. & mean $\pm \mathrm{SD}$ & value \\
\hline TFC & 30 & 2.03 & -0.20 & $0.64 \pm 0.53$ & \\
NON TFC & 30 & 2.01 & -1.30 & $0.42 \pm 0.84$ & 0.216 \\
\hline
\end{tabular}


Berdasarkan Tabel 2. menunjukkan bahwa selisih antara nilai rata-rata $z$-score $\mathrm{BB} / \mathrm{TB}$ yang mengikuti program TFC dengan yang tidak mengikuti program TFC adalah 0.22 . Nilai ratarata $z$-score $\mathrm{BB} / \mathrm{TB}$ balita TFC 0.64 dan balita non TFC 0.42 tergolong status gizi baik. Dari hasil uji perbedaan T-tes Independent diperoleh nilai $p=0.216(p \geq 0,05)$ Ho diterima yang berarti tidak ada perbedaan status gizi berdasarkan $\mathrm{BB} / \mathrm{TB}$ pada balita yang mengikuti program TFC dengan yang tidak mengikuti program TFC.

\subsubsection{Perbedaan Status Gizi Balita TFC dengan Non TFC Berdasarkan IMT/U}

Pengujian perbedaan status balita yang mengikuti program TFC dengan yang tidak mengikuti TFC berdasarkan IMT/U menggunakan uji T-Test Independent karena data penelitian berdistribusi normal. Hasil dapat dilihat pada Tabel 3.

Tabel 3. Perbedaan Status Gizi Balita TFC dengan non TFC Berdasarkan IMT/U

\begin{tabular}{|c|c|c|c|c|c|}
\hline \multirow{2}{*}{ Program } & \multicolumn{4}{|c|}{ Zscore IMT/U } & \multirow{2}{*}{$\begin{array}{c}p \text { - } \\
\text { value }\end{array}$} \\
\hline & $\mathrm{n}$ & $\max$. & $\min$. & mean \pm SD & \\
\hline TFC & 30 & 2.22 & -0.30 & $0.71 \pm 0.58$ & \multirow{2}{*}{0.145} \\
\hline NON TFC & 30 & 2.33 & -1.40 & $0.41 \pm 0.90$ & \\
\hline
\end{tabular}

Berdasarkan Tabel 3. menunjukkan bahwa selisih antara nilai rata-rata $z$-score $\mathrm{BB} / \mathrm{TB}$ yang mengikuti program TFC dengan yang tidak mengikuti program TFC adalah 0.30. Nilai ratarata $z$-score IMT/U balita TFC 0.71 dan balita non TFC 0.41 tergolong status gizi baik. Dari hasil uji perbedaan T-tes Independent diperoleh nilai $p=0.145(p \geq 0,05)$ Ho diterima yang berarti tidak ada perbedaan status gizi berdasarkan IMT/U pada balita yang mengikuti program TFC dengan yang tidak mengikuti program TFC.

\subsubsection{Pembahasan}

Awal penelitian, balita yang mengikuti program TFC dan balita yang tidak mengikuti program TFC belum mendapatkan intervensi seperti pemberian PMT dan modisco untuk balita yang mengikuti program TFC, dan untuk ibu balita belum mendapatkan edukasi gizi, tetapi tetap dilakukan penimbangan berat badan dan pengukuran tinggi badan. Hasil dari data penimbangan berat badan dan pengukuran tinggi badan diperoleh status gizi berdasarkan BB/TB pada balita yang mengikuti program TFC yaitu gizi normal sebanyak $43,3 \%$, gizi kurus sebanyak $33,3 \%$ dan gizi sangat kurus sebanyak 23,3\% sedangkan status gizi pada balita yang tidak mengikuti program TFC yaitu gizi normal sebanyak $50 \%$, gizi kurus sebanyak $23,3 \%$ dan gizi sangat kurus sebanyak $26,7 \%$. Status gizi berdasarkan IMT/U pada balita yang mengikuti program TFC yaitu gizi normal sebanyak 53,3\%, gizi kurang sebanyak $30 \%$ dan gizi sangat kurang sebanyak $16,7 \%$. Status gizi pada balita yang tidak mengikuti program TFC yaitu gizi normal sebanyak $60 \%$, gizi kurang sebanyak $16,7 \%$ dan gizi sangat kurang sebanyak $23,3 \%$.

Balita yang mengikuti program TFC selama 3 bulan akan dipantau status gizinya. Setiap seminggu sekali melakukan penimbangan berat badan, pengukuran tinggi badan dan pemeriksaan kesehatan. Balita juga diberikan PMT dan paket modisco yang berupa susu, gula dan minyak untuk dikonsumsi setiap hari. Ibu balita juga akan diberikan edukasi atau penyuluhan untuk menambah informasi tentang pengetahuan gizi. Balita yang tidak mengikuti program TFC selama 3 bulan juga dipantau status gizinya. Setiap satu bulan sekali di posyandu melakukan penimbangan berat badan, pengukuran tinggi badan dan pemeriksaan kesehatan. Balita juga diberikan PMT dalam bentuk seperti kue, buah dan bentuk olahan yang lain. Data penimbangan berat badan dan pengukuran tinggi badan yang diambil pada bulan terakhir diperoleh hasil status gizi berdasarkan $\mathrm{BB} / \mathrm{TB}$ pada balita yang mengikuti program TFC yaitu gizi normal sebanyak $73,3 \%$, gizi kurus sebanyak 23,3\% dan gizi sangat kurus sebanyak 3,3\% sedangkan status gizi pada balita yang tidak mengikuti program TFC yaitu gizi normal sebanyak $63,3 \%$, gizi kurus sebanyak $30 \%$ dan gizi sangat kurus sebanyak $6,7 \%$. Status gizi berdasarkan IMT/U pada balita yang mengikuti program TFC yaitu gizi normal sebanyak $80 \%$, gizi kurang sebanyak $16,7 \%$ dan gizi sangat kurang sebanyak 3,3\% sedangkan 
PROFESI (Profesional Islam)

Media Publikasi Penelitian; 2017; Volume 15; No 1.

Website: ejournal.stikespku.ac.id

status gizi pada balita yang tidak mengikuti program TFC yaitu gizi normal sebanyak $66,7 \%$, gizi kurang sebanyak $23,3 \%$ dan gizi sangat kurang sebanyak $10 \%$.

Selama 3 bulan memantau status gizi balita yang mengikuti program TFC dan balita yang tidak mengikuti program TFC terdapat perubahan status gizi. Kondisi status gizi balita sangat beragam, yaitu ada yang mengalami peningkatan status gizi, ada yang status gizinya tetap bahkan ada sedikit yang mengalami penurunan status gizi. Hasil perubahan status gizi balita berdasarkan BB/TB pada balita yang mengikuti program TFC yaitu status gizi yang naik sebanyak $46,7 \%$, tetap sebanyak $40 \%$ dan penurunan status gizi sebanyak $13,3 \%$ sedangkan perubahan status gizi pada balita yang tidak mengikuti program TFC yaitu status gizi naik sebanyak 33,3\%, tetap sebanyak $40 \%$ dan penurunan status gizi sebanyak $26,7 \%$. Perubahan status gizi berdasarkan IMT/U pada balita yang mengikuti program TFC yaitu status gizi yang naik sebanyak $40 \%$, tetap sebanyak $43,3 \%$ dan penurunan status gizi sebanyak $16,7 \%$ sedangkan perubahan status gizi pada balita yang tidak mengikuti program TFC yaitu status gizi naik sebanyak $30 \%$, tetap sebanyak $40 \%$ dan penurunan status gizi sebanyak $30 \%$.

Perubahan status gizi terjadi karena terdapat perubahan (kenaikan dan penurunan) berat badan anak. Kenaikan atau penurunan berat badan diperoleh dari selisih antara berat badan akhir dengan berat badan awal. Balita yang mengalami peningkatan status gizi dapat disebabkan oleh beberapa faktor yaitu orang tua balita memperhatikan penyuluhan atau edukasi gizi yang diberikan oleh petugas puskesmas sehingga orang tua balita lebih sering terpapar dengan pengetahuan gizi dan kesehatan melalui penyuluhan yang disampaikan dan orang tua balita dapat mengimplementasikan saran-saran yang diberikan oleh petugas ahli gizi sehingga terdapat peningkatan status gizi pada anak.

Balita yang mengalami penurunan status gizi dapat disebabkan karena kurangnya perhatian orang tua balita saat adanya edukasi gizi atau penyuluhan yang diberikan oleh petugas puskesmas, pesan-pesan yang diberikan oleh petugas ahli gizi tidak diingat, keluarga tidak dapat mengimplementasikan saran-saran yang diberikan petugas ahli gizi dan kesehatan anak yang menurun karena terkena infeksi. Sejalan dengan penelitian Ashworth (2006), mengemukakan bahwa terdapat alasan ketidakefektifan beberapa program penanggulangan masalah gizi kurang dan gizi buruk pada balita, antara lain makanan yang disediakan terlalu sedikit, makanan tidak cukup padat energi karena terlalu banyak air dalam penambahan makanan saat dimasak atau dilarutkan, kebiasaan makan anggota keluarga yang dapat mempengaruhi kebiasaan makan balita, ibu tidak memiliki waktu atau tenaga atau bahan untuk menyediakan makanan pada anak secara rutin, infeksi yang berulang karena keluarga hidup dalam lingkungan yang kumuh sehingga anak mudah terkena infeksi, makanan suplemen diganti dengan bahan makanan lain yang kandungan energinya tidak sama, kurang dukungan dari anggota keluarga yang lain, pesan-pesan yang diberikan tidak diingat, keluarga yang tidak mampu sulit untuk mengimplementasikan saransaran yang diberikan oleh petugas ahli gizi dan kehadiran yang tidak rutin atau jarang yang dikarenakan jarak terlalu jauh, kesempatan dan biaya.Berbeda dengan penelitian Tekeste, et al (2012) ada total 646 anak yang mengikuti TFC di Marocho, dan 616 anak-anak tersebut sembuh, dengan angka kesembuhan sebesar 95,36\%.

Seiring dengan pertambahan usia anak makanan yang dikonsumsi mulai beragam maka harus diberikan makananyang bergizi lengkap dan seimbang sehingga penting untuk menunjang pertumbuhan dan perkembangan anak (Sulistijani, 2001). Ajaran agama Islam menganjurkan umatnya untuk selalu mengkonsumsi makanan yang bukan hanya sehat, tetapi juga bergizi. Untuk itu agama Islam selalu mengajarkan pemeluknya untuk mengkonsumsi makanan bukan hanya halal tetapi juga thayib. Thayib itu sendiri dapat diartikan lezat, baik, sehat dan menentramkan (Shihab, 1996). Sesuai dengan QS. Al-Nahl ayat 114 "Maka makanlah yang halal lagi baik dari rezki yang telah 
diberikan Allah kepadamu; dan syukurilah nikmat Allah, jika kamu hanya kepada-Nya saja menyembah". Maksud dari ayat tersebut memerintahkan manusia untuk mengkonsumsi makanan yang halal dan baik, bersamaan dengan itu juga harus bersyukur atas berbagai nikmat yang diberikan Allah SWT (Hasbi, 1995). Selain itu dalam QS al-Nisa ayat 8 "Dan hendaklah takut kepada Allah, orang-orang yang seandainya meninggalkan dibelakang mereka anak-anak yang lemah, yang mereka khawatir terhadap kesejahteraan mereka oleh sebab itu hendaklah mereka bertakwa kepada Allah dan hendaklah mereka mengucapkan perkataan yang benar". Untuk merealisasikan anjuran ayat tersebut, diperlukan makanan yang bergizi, karena makanan yang bergizi sangat erat kaitannya dengan membangun kekuatan jasmani dan kecerdasan seseorang, semakin baik gizi yang dikonsumsinya akan menjadi kuat dan cerdaslah orang tersebut, begitu pula sebaliknya makanan yang tidak mengandung gizi yang baik, akan berakibat lemahnya fisik dan mental (Kartubi, 2013).

\section{SIMPULAN}

Tidak ada perbedaan perubahan status gizi berdasarkan $\mathrm{BB} / \mathrm{TB} \quad(p=0.216) \quad$ dan $\quad \mathrm{IMT} / \mathrm{U}$ ( $p=0.145$ ) pada balita gizi kurang yang mengikuti program TFC dengan yang tidak mengikuti program TFC. Tidak adanya perbedaan perubahan status gizi dikarenakan asupan makanan balita. Oleh karena itu, lebih meningkatkan kesadaran orang tua balita dalam memperhatikan tumbuh kembang anak dan asupan makan agar gizi anak tercukupi dengan baik sehingga memiliki status gizi yang baik pula. Bagi peneliti selanjutnya, melakukan penelitian lebih lanjut mengenai faktor yang mempengaruhi perubahan status gizi, tidak hanya faktor asupan makanan saja tetapi juga faktor infeksi.

\section{REFERENSI}

Adisasmito, W. 2007. Faktor Resiko Diare Pada Bayi Dan Balita Di Indonesia. Makara Kesehatan, 11, 1-10
Almatsier, S. 2009. Prinsip Dasar Ilmu Gizi. Jakarta: PT Gramedia Pustaka Utama.

Aritonang, Irianton. 2003. Pemantauan Pertumbuhan Balita. Jakarta: PT Kanisius.

Ashworth, Ann. 2006. Effcacy and Effectiveness of Community-Based Treatment of Severe Malnutrition. The United Nations University. Food and Nutrition Bulletin, vol. 27, no. 3 .

Departemen Kesehatan RI. 2003. Pedoman penyuluhan gizi dan kesehatan dalam penatalaksanaan balita gizi buruk secara rawat jalan untuk Puskesmas. Jakarta: Depkes RI, 2003.

Depkes RI. 2010. Laporan Hasil Riset Kesehatan Dasar (RISKESDAS). Jakarta: Badan Penelitian dan Pengambangan Kesehatan.

Depkes RI. 2011. Kinerja Dua Tahun Kementerian Kesehatan RI Tahun 20092011. Jakarta: Depkes RI.

Dinkes Sukoharjo. 2015. Prevalensi Data Status Gizi Balita Menurut Indeks BB/U. Sukoharjo.

Hasbi, Ashiddiqi. Tafsir An-Nur Jilid III, (Semarang: Pustaka Rezki Putra, 1995)

Kartubi. 2013. Keutamaan Mengkonsumsi Makanan Halalan Thayyiba. Edu-Bio; Vol. 4

Kemenkes RI. 2011. Pedoman pelayanan gizi buruk. Jakarta: Departemen Kesehatan RI.

Khomansan, D. 2012. Gizi Anak Sekolah. Jakarta: Buku Kompas.

Maria, D. N. Herawati, Yeny, S. 2012. Pengaruh Pemberian Makanan Tambahan (PMT) Terhadap Perubahan Berat Badan Anak Gizi Buruk,Usia 6-60 Bulan di Therapeutic Feeding Centre (TFC), Kecamatan Malaka Tengah, Kabupaten Belu, Nusa Tenggara Timur. Jurnal Kesehatan Masyarakat. Yogyakarta: Universitas Respati. 
PROFESI (Profesional Islam) Media Publikasi Penelitian; 2017; Volume 15; No 1.

Website: ejournal.stikespku.ac.id

Notoatmodjo. S, 2010. Metodologi Penelitian Kesehatan. Jakarta: Rineka Cipta.

Puspitawati, N \& Sulistyarini. 2013. Sanitasi Lingkungan yang tidak Baik Mempengaruhi Status Gizi pada Balita. Jurnal Kesehatan Masyarakat. Stikes.

Rahim FK. 2014. Faktor Risiko Underweight Balita Umur 7-59 Bulan. Jurnal Kesehatan Masyarakat.

Riskesdas. 2007. Pedoman Pewawancara Petugas Pengumpul Data. Jakarta: Badan Litbangkes, Depkes RI.

Riskesdas. 2010. Riset Kesehatan Dasar. Jakarta: Badan Penelitian dan Pengembangan Kesehatan Kementrian Kesehatan, Republik Indonesia.

Riskesdas. 2013. Status gizi anak balita berdasarkan indikator $B B / T B$. Jakarta.

SDKI. 2012. EstimasiAngka Kematian Bayi $(A K B)$ dan Angka Kematian Balita (AKABA). Jakarta.
Shihab, M. Quraish. 1996. Wawasan al-Quran, Bandung: Mizan.

Sugyono. 2007. Memahami Penelitian Kualitatif. Bandung: CV. Alfabeta.

Sulistijani. A.D. 2001. Menjaga Kesehatan Bayi dan Balita. Jakarta: Puspa Swara.

Tekeste, A. Wondafrash, M. Azene, G. Deribe, K. 2012. Cost Effectiveness of CommunityBased and Inpatient Therapeutic Feeding Programs to Treat Severe Acute Malnutrition in Ethiopia. Cost Effectiveness and Resource Allocation.

Tumiar, 2008. Status Gizi Balita Gizi Buruk Yang Memperoleh Makanan Tambahan Pemulihan (PMT-P) Di Kota Bengkulu. Tesis. Fakultas Kesehatan Masyarakat. Yogyakarta: Universitas Gajah Mada 